\title{
Placental biomarkers of phthalate effects on mRNA transcription: application in epidemiologic research
} Jennifer J Adibi*1, Russ Hauser ${ }^{1}$, Paige L Williams², Robin M Whyatt ${ }^{3}$, Harshwardhan M Thaker ${ }^{4}$, Heather Nelson ${ }^{1}$, Robert Herrick ${ }^{1}$ and Hari K Bhat ${ }^{3}$

\author{
Address: ${ }^{1}$ Department of Environmental Health, Harvard School of Public Health, Boston, MA, USA, ${ }^{2}$ Department of Biostatistics, Harvard Schoo \\ of Public Health, Boston, MA, USA, ${ }^{3}$ Department of Environmental Health Sciences, Mailman School of Public Health, New York, NY, USA and \\ ${ }^{4}$ Department of Pathology and Cell Biology, Columbia University, New York, NY, USA \\ Email: Jennifer J Adibi* - adibij@obgyn.ucsf.edu; Russ Hauser - rhauser@hohp.harvard.edu; Paige L Williams - paige@sdac.harvard.edu; \\ Robin M Whyatt - rmw5@columbia.edu; Harshwardhan M Thaker - thahara@gmail.com; Heather Nelson - hnelson@umn.edu; \\ Robert Herrick - herrick@hohp.harvard.edu; Hari K Bhat - hb2009@columbia.edu \\ * Corresponding author
}

Published: 23 April 2009

Environmental Health 2009, 8:20 doi:10.1186/1476-069X-8-20

This article is available from: http://www.ehjournal.net/content/8/I/20

(c) 2009 Adibi et al; licensee BioMed Central Ltd.

This is an Open Access article distributed under the terms of the Creative Commons Attribution License (http://creativecommons.org/licenses/by/2.0), which permits unrestricted use, distribution, and reproduction in any medium, provided the original work is properly cited.

\begin{abstract}
Background: CYPI9 and PPAR $\gamma$ are two genes expressed in the placental trophoblast that are important to placental function and are disrupted by phthalate exposure in other cell types. Measurement of the mRNA of these two genes in human placental tissue by quantitative real-time polymerase chain reaction (qPCR) offers a source of potential biomarkers for use in epidemiologic research. We report on methodologic challenges to be considered in study design.
\end{abstract}

Methods: We anonymously collected 10 full-term placentas and, for each, sampled placental villi at 12 sites in the chorionic plate representing the inner (closer to the cord insertion site) and outer regions. Each sample was analyzed for the expression of two candidate genes, aromatase (CYPI9) and peroxisome proliferator activated receptor protein gamma (PPAR $\gamma$ ) and three potential internal controls: cyclophilin (CYC), I8S rRNA (I8S), and total RNA. Between and within placenta variability was estimated using variance component analysis. Associations of expression levels with sampling characteristics were estimated using mixed effects models.

Results: We identified large within-placenta variability in both transcripts (>90\% of total variance) that was minimized to $<20 \%$ of total variance by using $18 \mathrm{~S}$ as an internal control and by modelling the means by inner and outer regions. 18S rRNA was the most appropriate internal control based on within and between placenta variability estimates and low correlations of I8S mRNA with target gene mRNA. Gene expression did not differ significantly by delivery method. We observed decreases in the expression of both transcripts over the 25 minute period after delivery (CYPI9 p-value for trend $=0.009$ and PPAR $\gamma(\mathrm{p}$-value for trend $=0.002)$. Using histologic methods, we confirmed that our samples were comprised predominantly of villous tissue of the fetal placenta with minimal contamination of maternally derived cell types.

Conclusion: QPCR-derived biomarkers of placental CYPI9 and PPAR $\gamma$ gene expression show high withinplacental variability. Sampling scheme, selection of an appropriate internal control and the timing of sample collection relative to delivery can be optimized to minimize within-placenta and other sources of underlying, nonetiologic variability. 


\section{Background}

The placenta is readily available yet underutilized in epidemiology as a biological marker of the effects of in utero exposures on the fetal/placental unit. As an endocrine organ, which plays a critical role in all aspects of pregnancy maintenance and fetal development, the placenta can provide insight into mechanisms by which specific exposures and risk factors are associated with outcomes measured at delivery. Outcomes which are placentallymediated include the timing of labor [1], preeclampsia $[2,3]$ intrauterine growth restriction $[4,5]$, and possibly endocrine [6,7] and neurologic diseases [8] which develop later in life. In the present study, we explored the utility of placental gene expression measured by real-time quantitative polymerase chain reaction (qPCR) as a novel biomarker for use in environmental epidemiology, including in our research on prenatal exposures to common endocrine disrupting chemicals called phthalates.

Phthalates have been shown to be reproductive and developmental toxicants in animal models with some preliminary evidence of effects in humans $[9,10]$. Urinary phthalate metabolites can be characterized as low dose chronic exposures in $>90 \%$ of pregnant women [11-13]. We chose to study the placenta as a potential target of phthalate toxicity during pregnancy. The placenta is a transient endocrine organ which assumes a wide range of functions to facilitate maternal-fetal interactions [14]. It supplants the ovary in the production, metabolism and regulation of steroid and other hormones necessary for pregnancy maintenance and fetal development [15]. The placenta, through autocrine and paracrine signaling, helps to maintain uterine quiescence until late pregnancy when a tightly regulated signaling cascade between the placenta, the fetus, and the uterus is initiated to stimulate uterine contractions [16]. Placental transporters can both block and facilitate xenobiotic entry into the fetal compartment [17].

The placenta is an extremely heterogeneous tissue and consists of several distinct cell populations. The main placenta cell type is the trophoblast which is fetal in origin and carries out most of the functions listed above. The maternal side of the placenta or basal plate emanates from the uterine wall and consists of trophoblastic and endometrium-derived cells. The fetal component or the placental villous is composed of a mixture of cell types including trophoblasts, the trophoblastic basement membrane, stroma (mesenchymal cells, macrophages, fibroblasts, and matrix components) and fetal vessels [18]. In the application of biomarkers of transcription, it is of critical importance to identify tissue type and cell type of interest and design methods to maximize the presence of these cells in any given biopsy. We were interested in tar- geting villous tissue and specifically gene targets expressed in the syncytiotrophoblast.

Existing, previously-validated methods for identifying toxic or pathologic responses in the human placenta include measuring the residues of the compound of interest in placental tissues [19-21]; documenting changes in morphology and histology as is done in routine pathological exams [22-24]; and looking at associations between the exposure and clinical cases of preeclampsia, placenta abruption and other clinical outcomes relevant to placental function [25-27]. DNA adducts have been measured in placental tissue and were associated with environmental exposures but not with enzyme activity, suggesting that they may not be good biomarkers of biochemical effects [17].

We were interested in identifying a biomarker that could be measured reliably and accurately in the placenta in an epidemiologic setting that was related to phthalate exposure and potentially relevant to effects at the molecular and clinical levels. Messenger RNA was chosen given the feasibility in measuring it in a large number of placentas and its clear physiologic relevance. qPCR was chosen over global gene expression microarrays, another commonly used method in studies using human placental tissue [2832], for two reasons. We had identified our gene targets based on apriori evidence from the toxicologic literature. Secondly, qPCR was more cost-effective given that our ultimate goal was to analyze a large enough number of samples $(\mathrm{N}>150)$ to be able to detect associations with common, low dose environmental exposures.

This validation study was undertaken to quantify underlying variability for two gene targets that will be used in our epidemiologic research: CYP19 (aromatase) and PPAR (peroxisome proliferator receptor protein gamma). CYP19 codes for the enzyme aromatase that is responsible for the conversion of androstenedione to estradiol in the placenta. Estradiol is essential for fetal development and parturition signaling [15]. CYP19 may also be important in the metabolism of xenobiotic compounds [33,34]. PPAR $\gamma$ is a transcription factor that has been shown to play an essential role in placental development and function through the regulation of genes involved in trophoblast differentiation, angiogenesis, fatty acid transport, and inflammation [35]. PPAR $\gamma$ null mice die during embryogenesis due to gross placental malformation and cardiac defects in the mouse [36]. The expression of both CYP19 and PPAR $\gamma$ were altered in response to phthalate exposure in rodent models [37-42]. Within the chorionic villi, PPAR $\gamma$ and CYP19 expression are expressed primarily by trophoblasts. In term placentas, PPAR $\gamma$ is localized to a large degree to the syncytiotrophoblast $[43,44]$ 
The purpose to the study was four-fold: (1) to evaluate variability in gene expression by placenta, by quadrant and by inner and outer regions of the chorionic plate; (2) to determine which of three potential internal controls was most appropriate; (3) to evaluate the effects of sampling characteristics on mRNA levels such as delivery method and time elapsed from delivery to sample collection; and (4), given the extremely heterogeneous nature of placental tissue, to assess the cell type composition in our tissue biopsies using histologic methods. Due to the fact that this study was conducted on discarded tissue and exempt from human subject protection, we were not able to collect subject-specific information other than time of delivery and delivery method.

\section{Methods}

Placental Samples: Ten full-term, discarded placentas were collected in the labor and delivery room at Morgan Stanley Children's Hospital of New York Presbyterian. Placentas were collected anonymously and thus IRB (Institutional Review Board) exemption was granted by Harvard School of Public Health (HSPH) IRB and the Columbia Medical Center IRB. The placentas included Caesarian deliveries (C-section) $(n=3)$, vaginal normal deliveries $(n=3)$, vaginal induced deliveries $(n=3)$, and one vaginal augmented delivery $(\mathrm{n}=1)$. Twelve tissue samples were collected per placenta according to the scheme in Figure 1a. A placental sampling device was used to orientate the fetal side of each placenta in relation to the umbilical cord (Figure 1b). The S1-S4 samples were categorized as 'inner' or from the area closest to the umbilical cord insertion. The Q1-Q8 samples were categorized as 'outer'. Care was taken by visual examination and dissection to minimize contamination from fetal membranes or maternal decidua and to maximize the amount of villous tissue in the sample. Each biopsy was taken approximately $1-1.5 \mathrm{~cm}$ below the fetal membrane to avoid membrane contamination as well as decidua contamination. The general dimension of each biopsy was 12 cubic centimeters and less than 1 gram in weight. Each sample was preserved in RNALater (Ambion, Austin, TX USA) to stabilize the RNA and stored at $4^{\circ} \mathrm{C}$. Within 30 days, samples were transferred to $-80^{\circ} \mathrm{C}$. Samples were collected between 3 and 25 minutes after delivery $(<=10$ minutes, $\mathrm{n}=3 ; 11-20$ minutes, $\mathrm{n}=3 ; 21-25$ minutes, $\mathrm{n}=4$ ). Samples were collected over one month in June July 2005.

RNA Analysis: Total RNA was isolated from approximately 300 mg of tissue using the RNeasy-Midi Kit (Qiagen, Valencia, CA). Genomic DNA contamination in the sample was minimized with a DNase digestion step. Total RNA was measured by determining absorbance at $260 \mathrm{~nm}$ using an Ultrospec 2100 Pro UV/Visible Spectrophotometer (GE Healthcare, Piscataway, NJ USA). RNA purity was assessed by the $\mathrm{A}_{260} / \mathrm{A}_{280}$ ratio (mean $=1.8, \mathrm{SD}=0.13, \mathrm{n}$ $=119$ ). We also ran the isolated RNA samples on analytical agarose gels. If the gel showed clear bands for $28 \mathrm{~S}$ and

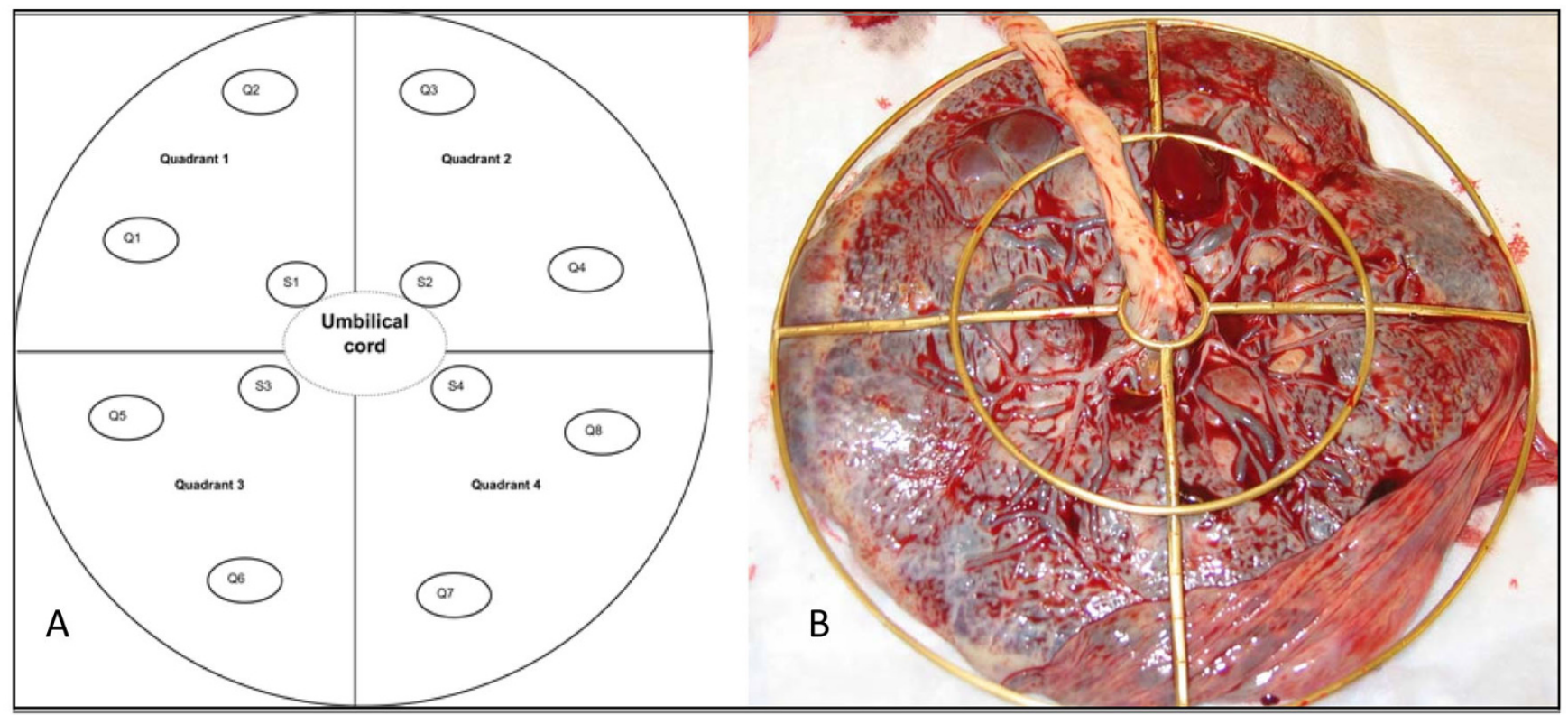

\section{Figure I}

Placental sampling scheme and device. a) Samples SI - S4 represent the "inner" region and samples QI - Q8 represent the "outer" region and b) Placenta is pictured looking down at the fetal side and the chorionic membrane. Sampling was carried out just below this membrane. 
18S, the samples were used for reverse transcription (RT). If not, we re-isolated the total RNA isolation from the same sample. Approximately $3 \mu \mathrm{g}$ total RNA were used in a RT reaction to synthesize cDNA using the First Strand SuperScript from Invitrogen (Carlsbad, CA USA). Finally, qPCR was used to quantitate differences in mRNA levels in each sample for individual genes. Cyclophilin (CYC) and $18 \mathrm{~S}$ ribosomal RNA (18S) were included as housekeeping genes to serve as internal controls for quantity and quality of cDNA going into the RT reaction. CYC was chosen based on a previous study that evaluated 3 housekeeping genes for use in human placental tissue analysis and found no difference between them [45]. 18S was later chosen as the consensus housekeeping gene based on the more recent placenta literature $[30,32,46,47]$. Total RNA ( $\mu$ g total RNA/sample) was also evaluated as a potential internal control $[48,49]$. All samples were analyzed for PPAR $\gamma$, CYP19, CYC and 18S mRNA using the ABI Prism 7500 Sequence Detection System (Applied Biosystems, Foster City, CA USA). Cycling conditions were the same for all four transcripts: 95.0 C for 5:00 minutes for activation of the enzyme, 95.0 C for 30 seconds for denaturation and 60.0 C for 1:00 minute for annealing/extension for 40 cycles, followed by a dissociation step. Forward and reverse primers (Sigma, St. Louis, MO USA) were either designed by Primer 3 [50] or selected for each gene to maximize specificity and efficiency in the reaction: CYP19 (249 base pairs (BP)) (forward) 5'-ATACCAGGTCCTGGCTACTG-3' and CYP19 (reverse) 5'-TCTCATGCATACCGATGCACTG-3'[51]; PPAR $\gamma$ (225 BP) (forward) 5'GCTGTGCAGGAGATCACAGA-3' and PPAR $\gamma$ (reverse) 5'GGGCTCCATAAAGTCACCAA-3'; CYC (116 BP) (forward) 5'-CCCACCGTGTTCTTCGACAT-3' and CYC (reverse) 5'-CCAGTGCTCAGAGCACGAAA-3'[52]; and $18 \mathrm{~S}$ (forward) 5'-CGGCTACCACATCCAAGGAA-3' and $18 \mathrm{~S}$ (187 BP) (reverse) 5'-GCTGGAATTACCGCGGCT-3' [53]. Each reaction used $2 \mu \mathrm{l}$ cDNA, forward and reverse primers at optimized concentrations, and SYBR Green PCR Core Reagents kit for a total reaction volume of $25 \mu \mathrm{l}$.

Specificity and Quantitation: Each sample was run in duplicate. The duplicate values not falling within 50\% of their mean were rerun. Specificity of the PCR product was evaluated using the melting curve generated at the end of amplification and by running a $2 \%$ agarose gel to visualize the PCR product. Absolute quantitation of mRNA concentration in the original sample was achieved using a standard curve generated for each batch [54]. Each standard curve included 2 non-template controls and 8 serial dilutions covering the range of 1000 molecules/ $\mu \mathrm{l}-1 \times$ $10^{7}$ molecules $/ \mu \mathrm{l}$. The standards for each gene were prepared as described previously [55]. The $\mathrm{R}^{2}$ for the standard curve was between 0.98-1.00. The plate was rerun if it fell below 0.95 . Ct (threshold cycle) values were use to evaluate batch effects. These are the raw data generated by the
qPCR and which are used in combination with the standard curve and the internal control to calculate the number of mRNA molecules in each sample. The number of target gene mRNA molecules for each sample was divided by the number of CYC or $18 \mathrm{~S}$ molecules or $\mu$ g total RNA for that same sample and expressed as a unitless ratio.

Histologic confirmation: Histologic confirmation of cell type composition was done by using a subset of 5 representative placentas selected from the full set of 10 placentas used for qPCR. From each placenta, a piece of tissue was cut from an inner sample (closer to umbilical insertion point) and an outer sample (closer to outer margin of the chorionic plate), treated with RNA-Later and stored long-term at -80 degrees Celsius. Later they were rinsed and fixed in formalin. They were then paraffin embedded, cut and stained with hematoxylin and eosin and examined by a placental pathologist.

Statistical analysis: Gene expression values were transformed to more closely approximate a normal distribution; for CYP19/CYC and CYP19/total RNA, we were able to approximate normality with a square root transformation and for all others we used a natural log transformation. One CYP19 value for placenta ID 2 and sample Q7 was extremely low ( $<2$ molecules mRNA/sample). We concluded that the original mRNA concentration was below detection and excluded it from the analysis. Two tissue samples were missing completely and three samples were missing $18 \mathrm{~S}$ values, reducing sample size from $\mathrm{N}$ (placentas) $=10$ and $n$ (tissues samples) $=120$ to $\mathrm{N}=10$ and $n=115$. The distributions of the untransformed values were summarized using means per placenta. Spearman correlation coefficients were used to evaluate correlations between genes within samples. Mixed effects models were used to estimate differences in gene expression by delivery method and time elapsed since delivery, and regional (inner versus outer placenta) differences. The correlation structure assumed equal variance between any 2 of the 12 samples. Variance component analysis was used to estimate between-placenta versus within-placenta variance. Statistical significance was set at $\mathrm{p}$-value equal to or less than 0.05. SAS 9.1 (SAS Institute, Cary, NC USA) software was used to conduct all analyses.

\section{Results and discussion Histologic confirmation of cell type}

The histologic analysis of RNA-Later treated sample confirmed that the samples were composed of placental villous tissue, with normal architecture and branching of the villi (Figure 2). There were no pathological changes, such as infarcts, hematomas, thrombi or inflammation in any of the 5 placentas evaluated. The syncytiotrophoblast was present in the expected proportion to the remainder of the cell types. Samples did not contain chorionic membrane. 


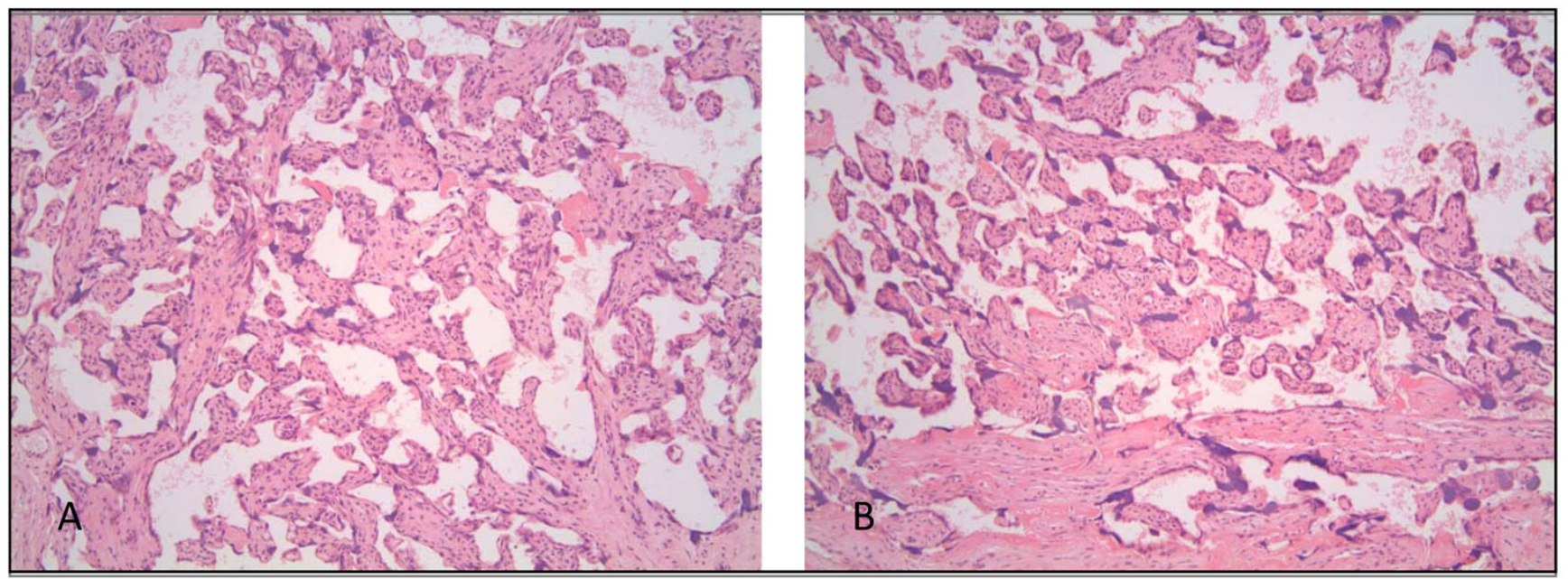

\section{Figure 2}

Histologic confirmation of cell type composition done with H\&E stained cross-sections of RNA-Later treated placental biopsies. a) inner region of a vaginally-delivered placenta and b) outer region of a vaginally-delivered placenta.

Decidual cells made up approximately $5 \%$ of the total nuclei based on what was viewed on the slide. We did not see any obvious differences in the histology or cell type composition between the inner and outer samples, or by quadrant.

\section{Distribution of total RNA and gene expression values}

Each tissue biopsy yielded on average $113 \mu \mathrm{g}$ total RNA/ sample (standard deviation $(\mathrm{SD})=108, \mathrm{n}=119$ ). The mean starting weight of the samples was $191 \mathrm{mg}$ (SD 57).
The median mRNA concentrations were highest for $18 \mathrm{~S}$ $\left(1.5 \times 10^{6}\right.$ mRNA molecules/sample), then CYP19 $(9.8 \times$ $\left.10^{5}\right)$, CYC $\left(4.4 \times 10^{5}\right)$ and lowest for PPARY $\left(1.0 \times 10^{4}\right)$. The coefficients of variation for the batch Ct values were all less than $10 \%$ (3\% for PPAR $\gamma$ and CYC, 6\% for CYP19, and $9 \%$ for $18 \mathrm{~S}$ ).

\section{Between vs. within placenta variability}

Within-placenta variability was greater than between-placenta variability for the 10 placentas when we used all 12

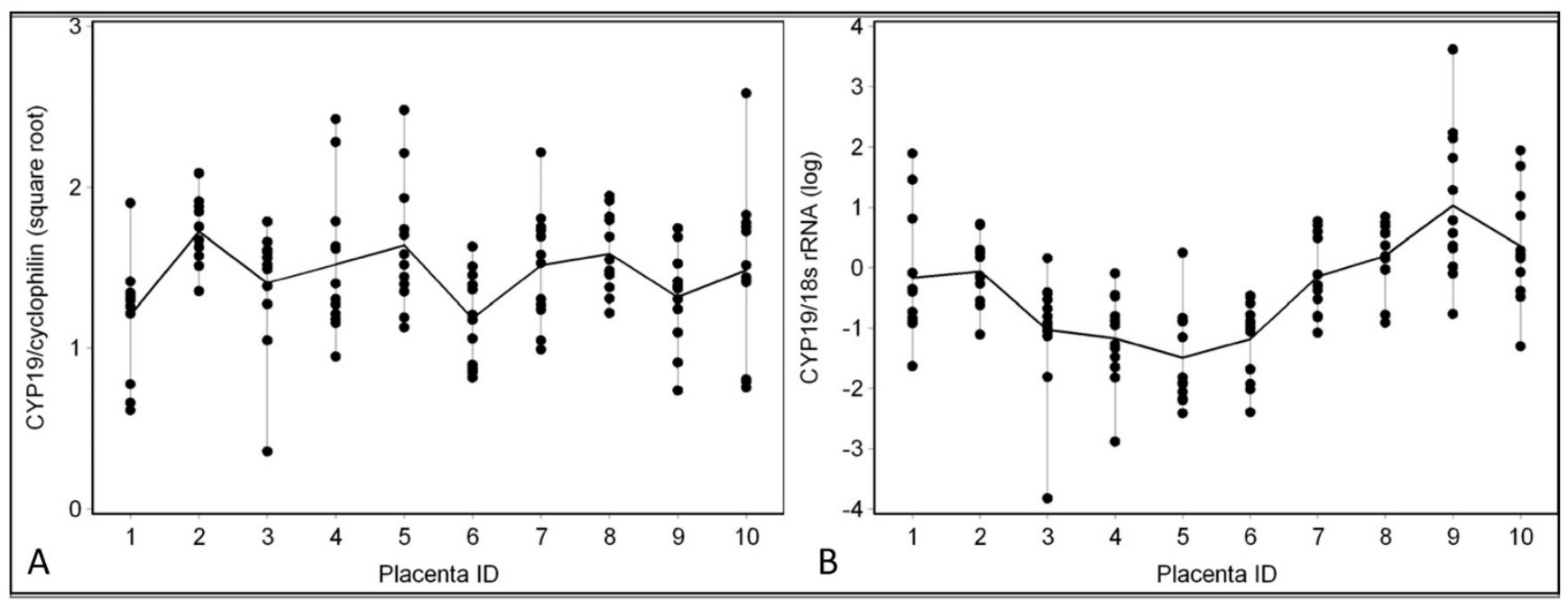

Figure 3

Raw data shows high within-placenta variation in gene expression that is highest when cyclophilin is used as an internal control compared to I8S. a) CYPI9 mRNA adjusted for CYC mRNA b). CYPI9 mRNA adjusted for I8S mRNA. The vertical lines and black dots represent values for individual biopsies within a placenta. The gray lines connect the median values per placenta. 
samples per placenta, ranging from 54 to $99 \%$ of the total variation (Table 1 and Figure 3 ). The ratio of between to within placenta variability also varied with different internal controls as seen in the comparison of Figures 3a vs. 3b and Figures $4 \mathrm{a}$ vs. $4 \mathrm{~b}$. Adjustment for CYC as an internal control produced the most extreme estimates in the ratio ( $>90 \%$ within-placenta variation of total variance). When we modelled the means by the 4 quadrants, the withinplacenta variability decreased to $50 \%$ or less of the total variability when values were adjusted for $18 \mathrm{~S}$ and total RNA (Table 1). The means in CYP19 values by inner and outer region of the chorionic plate (black and gray dots) were closely aligned when we adjusted for $18 \mathrm{~S}(<20 \%$ within-placenta variability) (Table 1, Figure 4b) and less closely aligned when we adjusted for cyclophilin (57\% within-placenta variability) (Table 1, Figure 4a).

\section{Spatial variability}

Samples taken from the inner region (area closer to the cord insertion point as depicted in Figure 1a) had higher PPAR $\gamma$ expression than samples taken further from the cord insertion point; although not statistically significant. There was no difference by region in CYP19 expression (Table 2). We did not include quadrant in the mixed effects models as they were intended to provide structure to the sampling scheme. The quadrants do not hold anatomic or physiologic significance.

Tissue heterogeneity as well as differences in perfusion and the degree of hypoxia are major sources of within-placenta variability $[31,45,46]$. Wyatt et al. did a detailed analysis of concordance between histologic parameters and gene expression using 6 placentas sampled at 9 sites including the chorionic (fetal side) and basal (maternal side) plates and the inner (medial) and outer (lateral) regions on both sides [46]. They observed evidence of higher expression of hypoxia-related placental transcripts in the areas with histology characteristic of lower perfusion, i.e. small villi, increased amounts of fibrin deposits, and common syncytial knots. They concluded that perfusion was highest in the maternal-side inner samples and the lowest in the fetal-side outer samples. Consistent with differences by degree of hypoxia, we also saw a nonsignificant trend towards higher expression of the hypoxia-related transcript PPAR $\gamma$ in the inner region. PPAR $\gamma$ is a regulator of the response to hypoxia in the trophoblast [56]. Our measure of the expression of the gene for the receptor gene could be directly or inversely correlated with increased hypoxia-induced ligand-receptor interaction depending on the types of feedback mechanisms involved.

\section{Normalization strategies: cyclophilin vs. I $8 S$ rRNA vs. total RNA}

Using unadjusted values, CYP19 was weakly but significantly correlated with the internal controls: CYC $(\mathrm{r}=$ $0.34), 18 \mathrm{~S}(\mathrm{r}=0.30)$, and total RNA $(\mathrm{r}=0.19)$. PPAR $\gamma$ was strongly correlated with CYC $(r=0.53)$, not correlated with $18 \mathrm{~S}(\mathrm{r}=0.05, \mathrm{p}=0.64)$, and weakly correlated with total RNA $(\mathrm{r}=0.18 \mathrm{p}=0.05)$.

The CYP19 - PPAR $\gamma$ correlation was significant regardless of internal control and strongest with $18 \mathrm{~S}$ adjustment $(\mathrm{r}=$ $0.85)$, also strong with total RNA adjustment $(\mathrm{r}=0.64)$,

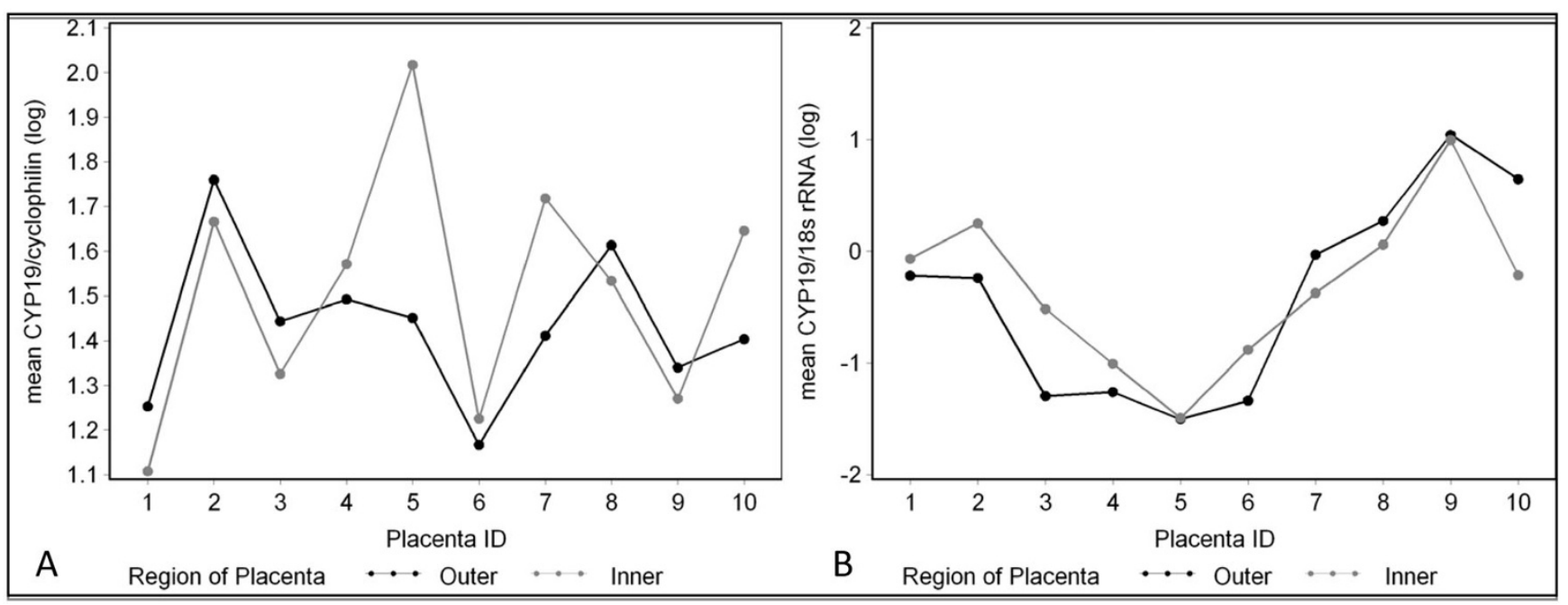

Figure 4

The means by inner and outer region show less within-placenta variation. a) mean CYPI9 mRNA adjusted for CYC mRNA b) mean CYPI9 mRNA adjusted for I8S mRNA. Black points represent the outer region and gray represents the inner region. 
Table I: Variance component analysis.

\begin{tabular}{|c|c|c|c|c|c|c|}
\hline & \multicolumn{2}{|c|}{ a) Cyclophilin } & \multicolumn{2}{|c|}{ b) I8S rRNA } & \multicolumn{2}{|c|}{ c) total RNA } \\
\hline & PPAR $\gamma$ & CYPI9 & $\operatorname{PPAR} \gamma$ & CYPI9 & $\operatorname{PPAR} \gamma$ & CYPI9 \\
\hline \multicolumn{7}{|c|}{ By sample number ( $n=\mid 2 /$ placenta) } \\
\hline Between & $1 \%$ & $8 \%$ & $36 \%$ & $46 \%$ & $26 \%$ & $37 \%$ \\
\hline Within & $99 \%$ & $92 \%$ & $64 \%$ & $54 \%$ & $74 \%$ & $63 \%$ \\
\hline \multicolumn{7}{|c|}{ By quadrant ( $n=4 /$ placenta) } \\
\hline Between & $9 \%$ & $14 \%$ & $53 \%$ & $67 \%$ & $50 \%$ & $66 \%$ \\
\hline Within & $91 \%$ & $86 \%$ & $47 \%$ & $33 \%$ & $50 \%$ & $34 \%$ \\
\hline \multicolumn{7}{|c|}{ By region ( $n=2 /$ placenta) } \\
\hline Between & $0 \%$ & $43 \%$ & $81 \%$ & $84 \%$ & $49 \%$ & $77 \%$ \\
\hline Within & $100 \%$ & $57 \%$ & $19 \%$ & $16 \%$ & $51 \%$ & $23 \%$ \\
\hline
\end{tabular}

Results vary when the target mRNA is adjusted by a) CYC; b) $18 \mathrm{~S}$ rRNA; and c) total RNA.

and weakest with CYC adjustment $(\mathrm{r}=0.25)$. There was no overlap in the $95 \%$ confidence intervals for these three correlation coefficients, suggesting that there are significant differences in the point estimate depending on which internal control is used. PPAR $\gamma$ is a potential regulator of CYP19 transcription in the trophoblast given its known relationship in the granulosa cell [57] and therefore we would expect their expression values to be correlated. If we used CYC as an internal control, we would have erroneously concluded that CYP19 and PPAR $\gamma$ expression were not correlated based on the considerably lower $\mathrm{r}$ value than when we used $18 \mathrm{~S}$.

Adjustment for an appropriate internal control should in theory minimize variability due to differences in the quality and quantity of the RNA that went into the RT reaction. Several possible internal controls have been proposed for qPCR including total RNA, ribosomal RNAs, and one or more reference messenger RNAs $[48,49,58]$. Reference mRNAs are the most common approach. Some of the criteria are that they be constitutively expressed in the cell type of interest, in the tissue of interest and not be affected by the exposure of interest or experimental conditions. The internal control should not share regulatory factors with the gene of interest. It should have low intra-individual variation and should be expressed at roughly the same order of magnitude as the target gene $[49,59]$.

Unlike Pidoux et al. (2004) who showed that cyclophilin was a suitable housekeeping gene in studies of PPAR $\gamma$ expression in the trophoblast, we found that cyclophilin was not tenable as a housekeeping gene in our conditions. It showed extremely high within-placenta variability that we speculate is related to its role in hypoxia therefore obviating its use as a housekeeping gene. Reports of CYC expression in other tissues showed that it was upregulated in response to hypoxia which would make it inappropriate for use in placental studies where hypoxia might be in the causal pathway between exposure and disease [60]. We also saw that CYC mRNA was correlated with PPAR $\gamma$ mRNA suggesting that they might share one or more reg-

Table 2: Sample collection characteristics as multivariate predictors of gene expression.

\begin{tabular}{|c|c|c|}
\hline & CYPI9/I8S (square root) & PPAR $\gamma / / 8 S$ (log) \\
\hline Mean (SD) by placenta & $-0.34(\mathrm{I} . \mathrm{I})$ & $-4.70(1.4)$ \\
\hline Characteristic & \multicolumn{2}{|c|}{$\beta$ coefficient (SE) $\mathbf{p}$-value } \\
\hline \multicolumn{3}{|l|}{ Delivery method } \\
\hline Vaginal vs. c-section & $0.28(0.39) \mathrm{p}=0.50$ & $0.52(0.31) p=0.15$ \\
\hline \multicolumn{3}{|c|}{ Time Elapsed since delivery up to 30 minutes ( $<=10$ minutes is referent) } \\
\hline II -20 minutes & $-0.82(0.39) p=0.08$ & $-1.24(0.32) p=0.008$ \\
\hline $21-30$ minutes & $-1.99(0.30) p=0.0005$ & $-2.12(0.40) p=0.002$ \\
\hline$p$-value for trend & 0.009 & 0.002 \\
\hline
\end{tabular}

\section{Regional differences}


ulatory factors. Previous reports have shown that PPAR $\gamma$ expression in the placenta is partly regulated by hypoxia $[61,62]$

We evaluated total RNA as a potential internal control. Total RNA is thought to vary minimally by cell and therefore be more stable within a tissue type, to be less variable by method of homogenization, more uniformly measured across studies, and possibly a more accurate measure of the quality of the tissue at the time of sampling [49,59]. We found that total RNA did better than CYC in controlling for within-placenta variation. However, it is problematic in that it does not take into account differences in reverse transcription efficiencies by which the synthesized cDNA may or may not be directly proportional to the amount of input total RNA $[48,49,59]$. To our knowledge, there are no published placenta studies that have used total RNA as an internal control.

Ribosomal RNAs such as $18 \mathrm{~S}$ have been recommended as reference genes in that they are generated by a polymerase distinct from those that generate mRNA, they are less likely to vary by conditions that affect the expression of mRNA, and they have been shown to be more reliable than other housekeeping genes in a variety of tissues [59]. $18 \mathrm{~S}$ appears to be the most commonly used reference gene in placental studies of gene expression $[30,32,46,47]$. Additional reference genes (SDHA, TBP and YWHAZ) have recently been proposed for placenta studies that are expressed are lower levels than $18 \mathrm{~S}$ and should be considered in future studies $[58,63]$.

\section{Effects of sampling characteristics on gene expression}

Lastly, we were interested in estimating to what degree sampling characteristics predicted variability in the target gene expression. We fit multivariate mixed effects models that simultaneously adjusted for delivery method, time elapsed from delivery and region (inner vs. outer) (Table 2). Target mRNA levels are adjusted for 18S. PPAR $\gamma$ expression was higher in vaginal deliveries although not statistically significant. There was no difference in CYP19 expression by delivery method.

All placentas were sampled within 25 minutes after delivery. $67 \%$ of C-section placentas were collected within 10 minutes of delivery vs. $14 \%$ of the vaginally-delivered placentas. Expression levels decreased with time from delivery to collection which could be due to tissue necrosis, lost of oxygen supply, changes in temperature, handling of tissue, etc. We observed significant decreases over 25 minutes in the expression of both transcripts (Table 2). We observed a trend towards higher PPAR $\gamma$ expression in laboring placentas which is consistent with reports that PPAR $\gamma$ plays a role in the production of uterine contractions through the regulation of cytokine and prostaglandin production $[64,65]$.
A common practice in clinical and basic research settings is to restrict to C-section placentas due to tighter control over the time of sampling relative to the birth of the baby. In a setting, i.e. prenatal phthalate exposure [66], where the exposure of interest may have a putative effect on parturition signalling, this type of exclusion may introduce bias and possibly preclude the detection of associations of interest. For this reason, we propose sampling placentas of all delivery methods and routinely recording detailed information on the method and conditions of labor and delivery to be used in the data analysis. Likewise, we recommend evaluating the impact of the time elapsed from delivery to collection on expression values of specific transcripts.

All of the placentas in this study were full-term. However, because the tissue collection was IRB-exempt we were not able to collect information on specific gestational age which has been shown to be associated with placental gene expression [32]. Other variables that would have been important in characterizing underlying variability in these transcripts are sex of the baby given that CYP19 expression is known to be sexually dimorphic $[67,68]$, and ethnicity of the mother and father to control for know polymorphisms $[69,70]$. Lack of control for these variables could have resulted in bias in the associations that we report here. Technician and batch effects could also be important. We did not see evidence of batch effects in this analysis based on Ct values and one researcher carried all of the sampling and analysis out over a short period. It would be informative in a future validation study to correlate CYP19 and PPAR $\gamma$ protein levels to mRNA levels in order to better understand the phenotypic significance of transcriptional markers. Messenger RNA gives us information on effects in gene regulation solely at the level of transcription, which is an important yet singular piece of a complex process.

\section{Conclusion}

In a small study to validate methods for measuring CYP19 and PPAR $\gamma$ placental gene expression for application in an epidemiologic study, we identified methodologic challenges which we were able to partly resolve for these two transcripts. The application of placental biomarkers of transcription in epidemiologic studies will allow for the testing of a wide range of hypotheses relating to environmental hazards in pregnancy and their potential role in fetal origins of disease. The primary challenge was developing a reproducible sampling scheme that can give a representative snapshot of gene expression for a given placenta while not being overpowered by the high withinplacenta variability in these two transcripts. In an epidemiologic analysis, the statistical ability to identify predictors of gene expression can be greatly diminished as the ratio of within placenta variance/total variance increases much over $50 \%$. 
Another challenge was the selection of an appropriate internal control that represents mRNA levels in the cell at the time of sampling independent of factors regulating the target mRNA. Thirdly, given that the placenta is a highly dynamic tissue that reaches its physiologic climax immediately prior to being sampled, characteristics such as delivery method and time elapsed from delivery can potentially introduce unwanted variability. As our goal was to measure gene expression in the fully differentiated endocrine cell type, the syncytiotrophoblast, we included an additional step to confirm that this cell type was present.

Based on the results of this study, we recommend sampling from different regions within the area of interest (i.e. fetal or maternal side) to capture physiologically relevant spatial variability. In order to target trophoblast expression, we devised an efficient design by sampling the inner and outer regions of the fetal side or chorionic plate. If more than two samples are collected, mean values for the inner and outer regions may be modelled as the dependent variable. Methods can be further tailored to reduce the impact of variability within a placenta when the objective is to compare gene expression profiles between placentas. Although, we cannot recommend a universally appropriate internal control for placental studies, $18 \mathrm{~S}$ seems to give the least within-placenta variation for CYP19 and $\operatorname{PPAR} \gamma$.

\section{List of abbreviations}

CYP19: aromatase; PPAR $\gamma$ : peroxisome proliferator activated receptor gamma; qPCR: quantitative real-time polymerase chain reaction; CYC: cyclophilin; $18 \mathrm{~S}$ : $18 \mathrm{~S}$ ribosomal RNA; IRB: Institutional Review Board; SD: standard deviation.

\section{Competing interests}

The authors declare that they have no competing interests.

\section{Authors' contributions}

JA conducted the placenta sampling, all lab analyses, data analysis and drafted the manuscript. HK provided mentorship and expertise in qPCR. RH, PW, RW, HN, RH and HK contributed to study design, data analysis and manuscript preparation. HT conducted the histologic analysis.

\section{Acknowledgements}

We thank Deliang Tang and the research and laboratory staff of the CCCEH for the collection, processing and storage of placental tissue and David Teoste for assistance in the design and fabrication of the placental sampling device. This research was funded by NIEHS ROI ESO I3543. JA's doctoral training was funded by The Harvard Education and Research Center for Occupational Safety and Health (T42 OH0084I6).

\section{References}

I. McLean M, Bisits A, Davies J, Woods R, Lowry P, Smith R: A placental clock controlling the length of human pregnancy. Nat Med 1995, I:460-463.
2. Hunter CA Jr, Howard WF: Etiology of hypertension in toxemia of pregnancy. Am J Obstet Gynecol 1961, 81:44 I-450.

3. Zhou Y, Damsky CH, Fisher SJ: Preeclampsia is associated with failure of human cytotrophoblasts to mimic a vascular adhesion phenotype. One cause of defective endovascular invasion in this syndrome? J Clin Invest 1997, 99:2 I52-2164.

4. Khong TY, De Wolf F, Robertson WB, Brosens I: Inadequate maternal vascular response to placentation in pregnancies complicated by pre-eclampsia and by small-for-gestational age infants. Br J Obstet Gynaecol 1986, 93: 1049-1059.

5. Salafia CM, Vintzileos AM, Silberman L, Bantham KF, Vogel CA: Placental pathology of idiopathic intrauterine growth retardation at term. Am J Perinatol 1992, 9:179-184.

6. Lindsay RS, Lindsay RM, Waddell BJ, Seckl JR: Prenatal glucocorticoid exposure leads to offspring hyperglycaemia in the rat: studies with the II beta-hydroxysteroid dehydrogenase inhibitor carbenoxolone. Diabetologia 1996, 39:1299-1305.

7. Seckl JR, Benediktsson R, Lindsay RS, Brown RW: Placental II beta-hydroxysteroid dehydrogenase and the programming of hypertension. J Steroid Biochem Mol Biol 1995, 55:447-455.

8. Redline RW: Severe fetal placental vascular lesions in term infants with neurologic impairment. Am J Obstet Gynecol 2005, 1 92:452-457.

9. Hauser R, Calafat AM: Phthalates and human health. Occup Environ Med 2005, 62:806-818.

10. Swan SH: Environmental phthalate exposure in relation to reproductive outcomes and other health endpoints in humans. Environ Res 2008, 108:177-184.

II. Adibi JJ, Whyatt RM, Williams PL, Calafat AM, Camann D, Herrick R, Nelson H, Bhat HK, Perera FP, Silva MJ, Hauser R: Characterization of Phthalate Exposure among Pregnant Women Assessed by Repeat Air and Urine Samples. Environ Health Perspect 2008, I1 6:467-473.

12. Swan SH, Main KM, Liu F, Stewart SL, Kruse RL, Calafat AM, Mao CS, Redmon JB, Ternand CL, Sullivan S, Teague JL: Decrease in anogenital distance among male infants with prenatal phthalate exposure. Environ Health Perspect 2005, I I 3: I056- 106 I.

13. Wolff MS, Engel SM, Berkowitz GS, Ye X, Silva MJ, Zhu C, Wetmur J, Calafat AM: Prenatal phenol and phthalate exposures and birth outcomes. Environ Health Perspect 2008, I I 6: 1092-1097.

14. Moore KL, Persaud TVN, Shiota K: Color atlas of clinical embryology. Philadelphia, PA: W.B. Saunders; 2000.

15. Strauss JF III, Martinez F, Kiriakidou M: Placental steroid hormone synthesis: unique features and unanswered questions. Biol Reprod 1996, 54:303-3II.

16. Challis JR, Bloomfield FH, Bocking AD, Casciani V, Chisaka H, Connor K, Dong X, Gluckman P, Harding JE, Johnstone J, Li W, Lye S, Okamura K, Premyslova M: Fetal signals and parturition. J Obstet Gynaecol Res 2005, 3 I:492-499.

17. Myllynen P, Pasanen M, Pelkonen O: Human placenta: a human organ for developmental toxicology research and biomonitoring. Placenta 2005, 26:36I-37I.

18. Benirschke K, Kaufmann P, Baergen RN: Pathology of the human placenta. 5th edition. New York: Springer; 2005.

19. Lucier GW, Nelson KG, Everson RB, Wong TK, Philpot RM, Tiernan $T$, Taylor M, Sunahara Gl: Placental markers of human exposure to polychlorinated biphenyls and polychlorinated dibenzofurans. Environ Health Perspect 1987, 76:79-87.

20. Kantola M, Purkunen R, Kroger P, Tooming A, Juravskaja J, Pasanen $M$, Saarikoski S, Vartiainen T: Accumulation of cadmium, zinc, and copper in maternal blood and developmental placental tissue: differences between Finland, Estonia, and St. Petersburg. Environ Res 2000, 83:54-66.

21. Lopez-Espinosa MJ, Granada A, Carreno J, Salvatierra M, Olea-Serrano $\mathrm{F}$, Olea $\mathrm{N}$ : Organochlorine pesticides in placentas from Southern Spain and some related factors. Placenta 2007, 28:63I-638.

22. Ghidini A, Salafia CM: Histologic placental lesions in women with recurrent preterm delivery. Acta Obstet Gynecol Scand 2005, 84:547-550.

23. Salafia CM, Maas E, Thorp JM, Eucker B, Pezzullo JC, Savitz DA: Measures of placental growth in relation to birth weight and gestational age. Am J Epidemiol 2005, 162:991-998.

24. Salafia CM, Pezzullo JC, Charles AK, Ernst LM, Maas EM, Gross B, Pijnenborg R: Morphometry of the basal plate superficial uteroplacental vasculature in normal midtrimester and at term. Pediatr Dev Pathol 2005, 8:639-646. 
25. Ananth CV, Oyelese Y, Prasad V, Getahun D, Smulian JC: Evidence of placental abruption as a chronic process: associations with vaginal bleeding early in pregnancy and placental lesions. Eur J Obstet Gynecol Reprod Biol 2006, I 28: I 5-2I.

26. Getahun D, Ananth CV, Peltier MR, Smulian JC, Vintzileos AM: Acute and chronic respiratory diseases in pregnancy: associations with placental abruption. Am J Obstet Gynecol 2006, 195: II80-II84.

27. Levine RJ, Maynard SE, Qian C, Lim KH, England LJ, Yu KF, Schisterman EF, Thadhani R, Sachs BP, Epstein FH, Sibai BM, Sukhatme VP. Karumanchi SA: Circulating angiogenic factors and the risk of preeclampsia. N Engl J Med 2004, 350:672-683.

28. Huuskonen P, Storvik M, Reinisalo M, Honkakoski P, Rysa J, Hakkola J, Pasanen M: Microarray analysis of the global alterations in the gene expression in the placentas from cigarette-smoking mothers. Clin Pharmacol Ther 2008, 83:542-550.

29. Enquobahrie DA, Meller M, Rice K, Psaty BM, Siscovick DS, Williams MA: Differential placental gene expression in preeclampsia. Am J Obstet Gynecol 2008, 199:e56I-5I I.

30. Soleymanlou N, Jurisica I, Nevo O, letta F, Zhang X, Zamudio S, Post $M$, Caniggia I: Molecular evidence of placental hypoxia in preeclampsia. J Clin Endocrinol Metab 2005, 90:4299-4308.

31. Sood R, Zehnder JL, Druzin ML, Brown PO: Gene expression patterns in human placenta. Proc Natl Acad Sci USA 2006, 103:5478-5483.

32. Winn VD, Haimov-Kochman R, Paquet AC, Yang YJ, Madhusudhan MS, Gormley M, Feng KT, Bernlohr DA, McDonagh S, Pereira L, Sali $A$, Fisher S): Gene expression profiling of the human maternalfetal interface reveals dramatic changes between midgestation and term. Endocrinology 2007, I 48:1059-1079.

33. Hakkola J, Pasanen M, Hukkanen J, Pelkonen O, Maenpaa J, Edwards $\mathrm{RJ}$, Boobis AR, Raunio $\mathrm{H}$ : Expression of xenobiotic-metabolizing cytochrome P450 forms in human full-term placenta. Biochem Pharmacol 1996, 51:403-4II.

34. Pasanen $\mathrm{M}$ : The expression and regulation of drug metabolism in human placenta. Adv Drug Deliv Rev 1999, 38:81-97.

35. Schaiff WT, Barak Y, Sadovsky Y: The pleiotropic function of PPARgamma in the placenta. Mol Cell Endocrinol 2006, 249: $10-15$.

36. Barak $Y$, Nelson MC, Ong ES, Jones YZ, Ruiz-Lozano P, Chien KR, Koder A, Evans RM: PPAR gamma is required for placental, cardiac, and adipose tissue development. Mol Cell 1999, 4:585-595.

37. Corton JC, Bocos C, Moreno ES, Merritt A, Cattley RC, Gustafsson JA: Peroxisome proliferators alter the expression of estrogen-metabolizing enzymes. Biochimie 1997, 79:15I-162.

38. Davis BJ, Maronpot RR, Heindel J]: Di-(2-ethylhexyl) phthalate suppresses estradiol and ovulation in cycling rats. Toxicol Appl Pharmacol 1994, I 28:216-223.

39. Davis BJ, Weaver R, Gaines LJ, Heindel J]: Mono-(2-ethylhexyl) phthalate suppresses estradiol production independent of FSH-cAMP stimulation in rat granulosa cells. Toxicol Appl Pharmacol 1994, I 28:224-228.

40. Lovekamp-Swan T, Jetten AM, Davis B]: Dual activation of PPARalpha and PPARgamma by mono-(2-ethylhexyl) phthalate in rat ovarian granulosa cells. Mol Cell Endocrinol 2003, 20I:|33-|4I.

4I. Maloney EK, Waxman DJ: trans-Activation of PPARalpha and PPARgamma by structurally diverse environmental chemicals. Toxicol Appl Pharmacol 1999, 161:209-218.

42. Xu Y, Agrawal S, Cook TJ, Knipp GT: Maternal di-(2-ethylhexyl)phthalate exposure influences essential fatty acid homeostasis in rat placenta. Placenta 2008, 29:962-969.

43. Sullivan $\mathrm{MH}$ : Endocrine cell lines from the placenta. Mol Cell Endocrinol 2004, 228: 103-119.

44. Rodie VA, Young A, Jordan F, Sattar N, Greer IA, Freeman DJ: Human placental peroxisome proliferator-activated receptor delta and gamma expression in healthy pregnancy and in preeclampsia and intrauterine growth restriction. J Soc Gynecol Investig 2005, 12:320-329.

45. Pidoux G, Gerbaud P, Laurendeau I, Guibourdenche J, Bertin G, Vidaud M, Evain-Brion D, Frendo JL: Large variability of trophoblast gene expression within and between human normal term placentae. Placenta 2004, 25:469.
46. Wyatt SM, Kraus FT, Roh CR, Elchalal U, Nelson DM, Sadovsky Y: The correlation between sampling site and gene expression in the term human placenta. Placenta 2005, 26:372-379.

47. Roh CR, Budhraja V, Kim HS, Nelson DM, Sadovsky Y: Microarraybased identification of differentially expressed genes in hypoxic term human trophoblasts and in placental villi of pregnancies with growth restricted fetuses. Placenta 2005, 26:319-328

48. Huggett J, Dheda K, Bustin S, Zumla A: Real-time RT-PCR normalisation; strategies and considerations. Genes Immun 2005, 6:279-284.

49. Sehringer B, Zahradnik HP, Deppert WR, Simon M, Noethling C, Schaefer WR: Evaluation of different strategies for real-time RT-PCR expression analysis of corticotropin-releasing hormone and related proteins in human gestational tissues. Anal Bioanal Chem 2005, 383:768-775.

50. Rozen S, Skaletsky HJ: Primer3 on the WWW for general users and for biologist programmers. In Bioinformatics Methods and Protocols: Methods in Molecular Biology Edited by: Krawetz S, Misener S. Totowa, NJ: Humana Press; 2000:365-386.

5I. Miyoshi Y, Ando A, Shiba E, Taguchi T, Tamaki Y, Noguchi S: Involvement of up-regulation of I7beta-hydroxysteroid dehydrogenase type $I$ in maintenance of intratumoral high estradiol levels in postmenopausal breast cancers. Int J Cancer 200I, 94:685-689.

52. Murphy RM, Watt KK, Cameron-Smith D, Gibbons CJ, Snow RJ: Effects of creatine supplementation on housekeeping genes in human skeletal muscle using real-time RT-PCR. Physio Genomics 2003, I2:163-174.

53. Vissac-Sabatier C, Coxam V, Dechelotte P, Picherit C, Horcajada MN, Davicco MJ, Lebecque P, Bignon YJ, Bernard-Gallon D: Phytoestrogen-rich diets modulate expression of Brcal and Brca2 tumor suppressor genes in mammary glands of female Wistar rats. Cancer Res 2003, 63:6607-66/2.

54. ABI: Absolute Quantitation Using Standard Curve Getting Started Guide. In Applied Biosystems 7300/7500/7500 Fast RealTime PCR System Edited by: Biosystems A. Foster City, CA: Applied Biosystems; 2006.

55. Bhat HK, Epelboym I: Quantitative analysis of total mitochondrial DNA: competitive polymerase chain reaction versus real-time polymerase chain reaction. I Biochem Mol Toxicol 2004, 18: 180-186.

56. Fournier T, Pavan L, Tarrade A, Schoonjans K, Auwerx J, RochetteEgly C, Evain-Brion D: The role of PPAR-gamma/RXR-alpha heterodimers in the regulation of human trophoblast invasion. Ann N Y Acad Sci 2002, 973:26-30.

57. Fan W, Yanase T, Morinaga H, Mu YM, Nomura M, Okabe T, Goto $\mathrm{K}$, Harada N, Nawata $\mathrm{H}$ : Activation of peroxisome proliferatoractivated receptor-gamma and retinoid $\times$ receptor inhibits aromatase transcription via nuclear factor-kappaB. Endocrinology 2005, 146:85.

58. Meller M, Vadachkoria S, Luthy DA, Williams MA: Evaluation of housekeeping genes in placental comparative expression studies. Placenta 2005, 26:60 I-607.

59. Bustin SA: Absolute quantification of mRNA using real-time reverse transcription polymerase chain reaction assays. J Mol Endocrinol 2000, 25:169-193.

60. Zhong H, Simons JW: Direct comparison of GAPDH, betaactin, cyclophilin, and $28 \mathrm{~S}$ rRNA as internal standards for quantifying RNA levels under hypoxia. Biochem Biophys Res Commun 1999, 259:523-526.

6I. Daoud G, Simoneau L, Masse A, Rassart E, Lafond J: Expression of cFABP and PPAR in trophoblast cells: effect of PPAR ligands on linoleic acid uptake and differentiation. Biochim Biophys Acto 2005, 1687: $181-194$

62. Bilban M, Haslinger P, Prast J, Klinglmuller F, Woelfel T, Haider $S$, Sachs A, Otterbein LE, Desoye G, Hiden U, Wagner O, Knofler M: Identification of novel trophoblast invasion-related genes: heme oxygenase-I controls motility via peroxisome proliferator-activated receptor gamma. Endocrinology 2009, 150:1000-1013

63. Murthi P, Fitzpatrick E, Borg AJ, Donath S, Brennecke SP, Kalionis B: GAPDH, I8S rRNA and YWHAZ are suitable endogenous reference genes for relative gene expression studies in pla- 
cental tissues from human idiopathic fetal growth restriction. Placenta 2008, 29:798-80I.

64. Dunn-Albanese LR, Ackerman WEt, Xie Y, lams JD, Kniss DA: Reciprocal expression of peroxisome proliferator-activated receptor-gamma and cyclooxygenase-2 in human term parturition. Am J Obstet Gynecol 2004, 190:809-816.

65. Lappas M, Permezel M, Rice GE: I5-Deoxy-Delta( / 2, | 4)-prostaglandin $J(2)$ and troglitazone regulation of the release of phospholipid metabolites, inflammatory cytokines and proteases from human gestational tissues. Placenta 2006, 27:1060-1072.

66. Latini G, De Felice C, Presta G, Del Vecchio A, Paris I, Ruggieri F, Mazzeo P: In utero exposure to di-(2-ethylhexyl)phthalate and duration of human pregnancy. Environ Health Perspect 2003, I I I:1783-I785.

67. Dieudonne MN, Sammari A, Dos Santos E, Leneveu MC, Giudicelli Y, Pecquery R: Sex steroids and leptin regulate I I beta-hydroxysteroid dehydrogenase I and P450 aromatase expressions in human preadipocytes: Sex specificities. I Steroid Biochem Mol Biol 2006, 99: 189-196.

68. Hutchison JB, Schumacher M, Hutchison RE: Developmental sex differences in brain aromatase activity are related to androgen level. Brain Res Dev Brain Res 1990, 57:187-195.

69. Bower JF, Davis JM, Hao E, Barakat HA: Differences in transport of fatty acids and expression of fatty acid transporting proteins in adipose tissue of obese black and white women. Am J Physiol Endocrinol Metab 2006, 290:E87-E9I.

70. Haiman CA, Stram DO, Pike MC, Kolonel LN, Burtt NP, Altshuler D, Hirschhorn J, Henderson BE: A comprehensive haplotype analysis of CYP I 9 and breast cancer risk: the Multiethnic Cohort. Hum Mol Genet 2003, I 2:2679-2692.

Publish with Bio Med Central and every scientist can read your work free of charge

"BioMed Central will be the most significant development for disseminating the results of biomedical research in our lifetime. "

Sir Paul Nurse, Cancer Research UK

Your research papers will be:

- available free of charge to the entire biomedical community

- peer reviewed and published immediately upon acceptance

- cited in PubMed and archived on PubMed Central

- yours - you keep the copyright 